ARTICLE

\title{
CRITICAL-DISCURSIVE SOCIAL CONSTRUCTIONISM: WHAT IS THE STANDPOINT OF SOCIAL CONSTRUCTIONISM RESEARCH?
}

\author{
Martínez Richard, Janicce $* a$ \\ a. Universidad Simón Bolivar, Caracas, Venezuela. \\ *Corresponding author (usbnotas@gmail.com)
}

PUBLISHED: 31/07/2021

\section{COPYRIGHT NOTICE:}

(i) (C) 2021 by author. Licensee ERUDITUS. This article is an open access article distributed under the terms and conditions of the Creative Commons Attribution (CC BY) license (https://creativecommons.org/licenses/by/4.0/).

\section{CITE THIS PAPER:}

Martínez Richard, J. 2021. "Critical-discursive social constructionism: What is the standpoint of social constructionism research?" Journal of Social Sciences: Transformations \& Transitions (JOSSTT) 1(01):05. DOI: https://doi.org/10.52459/josstt1150721

\begin{abstract}
An overview of critical-discursive Social Constructionism is presented, showing its historical development and its critique of any methodological approaches that do not take into consideration the social-historical reality. In particular, it criticises the dualistic 'external object - cognitive subject' position of the Positivist current that has its roots in the Enlightenment and later in Modernity, which leads to a conception of reason and scientific truth as supposedly incontrovertible realities outside of any historical and social construction. Finally, social constructionism is presented not as a formal theory grounded of strict methodological principles, but rather as an approach that attempts to show the limitations of certain scientific or methodological views, emphasising the importance of social construction through language and the relative relevance of different positions, from which a certain vindication of epistemological relativism emerges.
\end{abstract}

\section{KEYWORDS}

Social Constructionism, Discursivity, Epistemology, Language, History 


\section{RESEARCH}

Some obvious references of social constructionism are Keneth Gergen in the Anglo-Saxon world, and Tomás Ibáñez and Lupicinio Íñiguez in the Spanish-speaking world. Also it's worth mentioning of the British researchers Potter, Wetherell, Parker, Billig, Edwards, Antaki, and others.

These thinkers propose social constructionism, not as something that is discovered, but rather as a form of intelligibility (Gergen, 1996), or as a movement (Ibáñez, 1994) that activates self-critique in psychology, especially in social psychology. A device that does not simply accept the illusions of stability inherent in the most and/or best accepted ideas of the discipline, including those produced by social constructionism, but rather purports to rethink them (Ibáñez, 1996).

It is difficult to attempt a strict definition of social constructionism that would not contradict its own proposal. However, some meaning can be discerned about key aspects in Gergen's writing (1996):

... the concepts by which both the world and the mind are referred to are constitutive of discursive practices, are embedded in language, and are therefore socially contested and subject to negotiation. Social constructionism is neither dualist nor monist (current debates on these issues are, in the eyes of the constructionist, first and foremost exercises in linguistic competence). (...) Social constructionism (...) refers the sources of human action back to relationships, and the very understanding of "individual functioning" is referred back to communal exchange. (p. 61)

Furthermore:

Arguments in favour of constructionism are, after all, social artefacts: bound together by metaphor and narrative, historically and culturally constrained, and used by people in the process of establishing relationships. (p. 69)

Both Gergen and Ibáñez agree that the very agenda of social constructionism best expresses its own constitution and perspective, its first step being a brief passage through key intellectual antecedents that end up giving ground and visibility to the crucial points of the agenda, as summarised by Ibáñez (2003):

... [It takes back] to the approaches of Michel Foucault, on the one hand, to the developments of the second "linguistic turn" led by the Oxford School, on the other hand, and also to the resurgence of "pragmatism" by Richard Rorty, as well as the rise of "post-structuralism", without forgetting the constitution of the "complexity paradigm", nor the growing attention paid to "discursivity" and "post-modern" approaches (p. 157).

This agenda "does not need the abandonment of traditional enterprises and endeavours. Rather, it places them in a different framework, with a resulting shift in emphasis and priorities" (Gergen, 1996, p. 29). 
Thus, the 'reality-knowledge' duality is the foundation of the argumentative artefact, and its analysis unveils the four powerful myths that run through Modernity (Ibáñez, 2001), namely: the myth of valid knowledge as a correct and reliable representation of reality, the myth of the object as a constitutive element of the world, the myth of reality as an entity independent of us, and the myth of truth as the ultimate criterion. Gergen (2007) undertakes a critical review of these myths as constituting a two-sided concept of knowledge: an exogenic, world-centred tradition (emphasizing knowledge as an accurate reflection on the external) and an endogenic, mind-centred tradition (emphasizing knowledge as an inner event): "Both views entail a mind/world dualism, wherein the existence of an external world (typically, a material reality) is counterposed to the existence of a psychological (cognitive, subjective, symbolic) world." (p. 214). This makes us prey to what Ibáñez calls "the ideology of representation" (2001, p. 246).

Social constructionism thus becomes a psychological approach that starts from the problematising premise (in Foucault's sense) of "making alien something that seems very obvious, very coherent" (Parker, 1999, p. 86). In other words:

Problematising is not only to make the unproblematic problematic - it would be too simple -, it is something much more important than this, because problematising is also, and above all, to get to understand how and why something has acquired the status of unquestionable evidence, how something has established itself as aproblematic. The fundamental aspect of problematisation is revealing the process through which something has been constituted as obvious, evident, certain. (Ibáñez, 1996, p. 54)

In this way, the purpose of questioning the reality conceived under the understanding of nature becomes central, that is to say, to question the presupposition that creates reality outside of us, with absolute independence of those who participate in it. Now, once reality has been examined, social constructionism is forced to denaturalise it.

According to the conception of reality as something external to the subjects who know it, multiple effects are produced that affect the very ways of knowing; this is what social "constructionism" "deconstructs", reflecting on the consequences that this had and still has on the spheres of science and everyday life.

Social constructionism owes sensitive contributions to symbolic interactionism (SI) and to the turn that, since Mead (1973), opens up, undergoes and is undergone by microsociology (MS), but it is worth clarifying that it differs both from MS and IS in the following crucial points: 1) the questioning of representationism as an undeniable onto-epistemic basis, according to the programme of the Enlightenment and, in general, of Modernity; and, consequently, 2) not assuming language as a reflection of the world, simply as a/the means to access the mind or experience.

Despite the rich dialogical relationship born of these affinities, there are also substantial differences, beginning with the first position ascribed to mental processes within those 
perspectives. Schutz argued that the concepts of "cognitive frame", "subjectivity", "attention", "reasons", and "goals" are central to the explanation of action. Similarly, Mead and other symbolic interactionists elaborated in full detail on concepts such as "symbolisation", "consciousness", "conceptualisation", and "self-concept". And Vygotsky paid special attention to the mental processes of "abstraction", "generalisation", "volition", "association", "attention", "representation", "judgement", and so on. Thus, all these theorists objectified a specifically mental world. In contrast, the main focus of interest for the constructionist is the micro-social process. The constructionist rejects the dualistic premises that give rise to the "problem of mental functioning". Thus the locus of explanation that accounts for human action is shifted to the relational sphere... (Gergen, 1996, p. 62).

A further difference must be added: 3) the issue of power (also here in Foucault's [1997] sense, i.e. polymorphous relations), the central focus of any relational spectrum, hence concerning how all knowledge, as a human production, has power effects (the knowledge-power relationship which Foucault understands as the "technical and epistemological unblocking" that accompanies scientific knowledge "and a whole series of social practices." [1978a, p. 21]). Disarticulating the preceding, as purported by the constructionist perspective, amounts to test the supposed independence of the influences from the subject, 'a producer of knowledge on

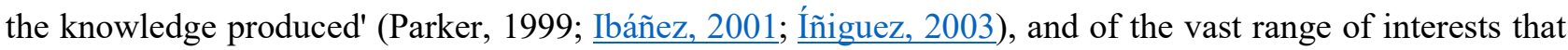
concur and transcend communities and epochs.

Neutrality and objectivity, central aspects of scientific research that in the human and social sciences follow the model of the natural sciences and the ways of working with their objects of study, put the latter in trouble when it comes to accounting for the object of research and the subject who does the research, both involved in a world of meanings (Mc Namee, 1996), very difficult to 'vacuum seal' in order to silence, lessen or counteract the noise or friction produced by a flexible and unpredictable human production (Billig, 1987).

Psychology had to face this issue from its beginnings, with Wundt's detailed laboratory work, within the concert of disciplines that, despite working with a human object, assure us that it is capable of controlling it as natural science has so far controlled, with proven success, its own. Wundt was a theoretician according to his time. He formalised the practice of psychology in the operations of the laboratory, but was concerned, above all, with how to enter the invisible realm of the mind (Fernández-Ch, 2010). This beginning marks early on the blurred boundaries of psychology, which will not infrequently struggle less with its own agenda than with methodological procedures in order not to depart from its status as a scientific discipline.

... Eighteenth-century views were later recorded in nineteenth-century writings about mental life (e.g., the works of Wundt and Titchener). Today they continue to reverberate in widely shared assumptions that (...) mental processes are available to be studied objectively (...) and that the experimental method is superior to all others in its ability to capture these causal relationships. (Gergen, 2007, p. 96) 
An imprint that persists still as dominant in psychological research, although debates about qualitative methods as an alternative are increasingly gaining interest and seducing other areas of the discipline (as well as other disciplines).

Wallerstein $(1999 ; 2006)$ records that it was in the mid-1960s when the historical conditions were in place to begin to speak properly of Social Sciences, due in particular to the fragmentations in research centres and universities, whose previous classifications into fields of study and thematic relevance were becoming obsolete, if they were to respond to the demands of scientific knowledge arising from the so-called 'sciences of man'. This movement led to new reclassifications, new disciplinary areas, new subjects of study and, of course, new objects of research. In this context, the term "social sciences" appeared, which, without much difficulty, brought together the world of the humanities and social disciplines.

Psychology was affected not only by the shocks that were constantly emerging, but it was also less and less able to avoid its own aporias, as the design of models from the empiricist demands reproducing the ontological and epistemological coordinates of positivism, were consolidating - together with the practices from diverse areas of study - what is known today as "the inherited view". It is within this inherited conception that the decisive questions that still continue to trouble psychology and its object would arise. This climate of upheaval inevitably resulted in psychology accrediting itself as a human science and, later, as a social science, in the extent that, as a human science, it could not renounce the diverse influences within its object.

Moving from the conception of 'environmental influence' to 'contextual determinations', with all that this entails (indexicality, inconclusiveness and reflexivity; Woolgar, [1988]), has been a less long than conflictive journey that still arouses mistrust on those that fear to jeopardise the focus of its object of study and/or its scientific status. But not only the approaches most reluctant to the changes within psychology, but also some attempts to change, still persist today without questioning the most sensitive aspects that concern the discipline, namely, the inherited view. Parker gives a fine example of this: "Ethnomethodology allows for an exploration of the ways people use in their daily lives to make sense of life and themselves (...). But this rejection of theory leads us to descriptions of behaviour that often go no further than empiricism" (1999, p. 100). So, the author criticizes even microsociology insofar as it did not manage to answer every aspect that positivism had left inscribed on the scientific procedure, and then, on any practice aspiring to the status of science.

\section{The relation subject-object/knowledge-reality}

The ideology of representation, as Ibáñez (2001) calls it, imposes a way of thinking about the world in such a way that one thing (something that is out there) is reality, whereas another, separate thing, is the subject. The latter, consequently, holds an 'inside' in opposition to that which is external. Hence, the outside is represented as separate and alien to the subject. This is a successful achievement of positivism, since it is there 
that the four myths mentioned above find a nest; whether the exterior or the interior world is privileged, its underlying effect is no different:

The endogenous tradition is similar to the exogenous in its dualistic foundations and its emphasis on value neutrality. However, while the exogenic tradition treats careful observation of the world as if it were the key to acquiring knowledge, the endogenist places the main emphasis on the powers of individual reason. (Gergen 2007 p. 214)

Dualistic positions can be traced further back (Enaudeau, 1999): Plato (in the Cave we only see forms, silhouettes, that reflect something we do not see); Descartes (the mechanistic model of the body versus the mechanistic model of the universe, the inside and the outside); Kant (appearance and essence, the latter being inaccessible and, consequently, unfathomable). However, what positivism adds is the legitimacy of scientific discourse in the consecration of these paradigms of fixity, since neither reality nor the subject can question each other or even move from the ontologically prescribed place for each, and the faculty of knowing is a consequence of such a split. It was not Comte (1974) who charged a specific weight to his Positive Discourse; rather it would be common usage together with specialised thinking, with the advantages of a social order that had moved from the King to the State and was in full industrial strength (Hobsbawm, 1989; Foucault, 1978b). It was so that this discourse established itself with definite forms of conceiving, acting and saying, thus validating Science to the status of Reason as the instrument of truth. Auguste Comte's programme, starting from a theological stage, going through a metaphysical stage and finally arriving, as a fatal destiny, at the last and definitive positive stage, provides a foundation for Reason as a predestined, unappealable and unpostponable plan. Anything else would amount to a delay or retardation in the linear, homogeneous and invariable course of the superior phase of knowledge.

It is encouraging to believe that individuals endowed with the faculties of reason and attentive to the features of the objective world can transcend the ambiguities of continually changing avatars and move towards a self-determined prosperity. And it is largely through this faith in reason that we are impelled to seek rational foundations of knowledge. From nineteenth-century positivism to the transcendental realism of the current century, scholars have supported the foundationalist tradition, ensuring that individual reason remains firmly in command of action. (Gergen, 1996, p. 1)

Thus, reason becomes the ultimate answer to all things, being justified by scientific discourse (Woolgar, 1991) from premises such as the separation of subject and reality which, though not unprecedented, will play the legitimising role of the Enlightenment by placing scientific reason as equivalent to truth (what Ibáñez denounces as "rhetoric of Truth" and its effects of power [2001, p. 247]). So, knowledge and technique become sovereign, independent and impervious to whatever human decision, leaving the researcher (the human subject who researches) separate from any criterion of validity, which resides fully and exclusively in Reason, Knowledge and Method, all without social connections: 
The only solution consists in placing the criterion of truth outside history, outside culture, outside society, outside the world of practices and simple human productions, that is to say, in short, outside what is contingent and variable. (Ibáñez, 2001, p. 254)

Total or partial separation of subject and object is shown in the autonomous, independent and selfsufficient character granted to reality, which becomes "the tribunal of facts" (Ibáñez's words), and in the passive, automatic acceptance of certain procedures capable of making correspond, as faithfully as possible, 'the observed facts and reality' —in other words, Method is the only guarantee of reliable, objective and neutral knowledge, that is, scientific knowledge (Ibáñez, 1996).

And so, the objective/subjective duality came to highlight the former, while the subjective remained on the margins; a marginality that Parker (1999) refers to as an interpretative vacuum. In order to avoid impurities in the research and production of knowledge, all subjective influence had to be actively avoided, that is, the researcher - the ultimate producer of knowledge - came to be considered as 'someone capable' of becoming 'something capable' of not interfering in what he/she researches and produces. A presupposition that Gadamer (1977) understands as an unconscious prejudice, as the researcher goes as someone without history, memory or tradition. The researcher is that 'something' without any component that would hinder research, thus fulfilling the illusion that there is no interpretative vacuum, since the reliability and validity of methods and the internal capacities to process external information would suffice to account for reality.

However, highlighting how subjectivity was set aside, tends to distract from the strengthening of the modern internal/external dualism through the consecration of exact, replicable procedures dictated by the hegemony of experimentalism and its logic, which gradually shape a regime of certainties rooted on absolute neutrality. As a result, reality is taken for granted as a fixed nature for the subject who contemplates it, even if he or she believes that they are aware of the obscure influence of an inner world.

It can be argued, in defence of Modernity, that as both science and technology advance, the 'human being' more than ever sets himself up as 'master and lord of nature', a result that does not contradict but rather works in favour of consolidating reality as an isolated, independent object, which will be controlled more and more, if not better and better. This task consolidates - but also hypertrophies - the concept of "modern individual", that is, "man" at the centre of nature as a privileged object of exploration. Agamben highlights that the technologies of the self (as mentioned by Foucault, [1996]) situate 'man' as a productive target of control, making him the object of specific or biopolitical technologies, "i.e., the increasing involvement of man's natural life in the mechanisms and calculations of power". (Agamben, 1998, p. 151)

Now, the axiom that critical-discursive social constructionism strips bare (by separating into parts and questioning how these parts became a coherent whole, i.e., exposing the constructed character of a supposedly monolithic whole), is none other than the assumption that knowledge is about reality. Hence, the priorities: what we know, how we know and who knows, imply, on the one hand, a reality perfectly separate from the subjects who knows (claiming 'objective' procedures that represent reality as accurately as possible) and, on 
the other, a subject who knows, whose asepsis as knower excludes any influence in the knowledge that he/she 'discovers', just because reality simply shows up as 'this or that' that the Method detects, apprehends, and shows from its absolute neutrality.

Critical constructionism puts in question the roadmap of Modernity, in particular, the consequences that follow from "the ideology of representation". Against the inherited view's strong claims of the independence of 'reality' from 'knowledge', such as the concept of valid knowledge, the object as a constitutive element of the world, reality as an entity independent of us, and truth as a definitive criterion (Ibáñez, 2001), social constructionism wields, as a refutation, the traps involved in any uncritical approach that does not take into account the historical, i.e. provisional, nature of these assumptions, and how this hinders new perspectives in research, not only with reference to theory (inseparable from action), but also with reference to the 'what' and the 'how' that have blocked the 'what for'. These ontological, epistemological, methodological, political and ethical questions that run through psychology (Ibáñez, 2005) finally recuse: the myth of representation, since there is no decision that is not subject to (social) conventions; the myth of the object that is now de-reified, de-naturalised and de-essentialised; the myth of independent reality, because reality exists as a collective construction; and the myth of truth, which is undermined in its supposed absolute and transcendent character (Ibáñez, 2001).

The critical operation of social constructionism shows the fallacy of the subject/object relationship as isolated and separate elements, and submits to extensive examination the ideology of representation, that is, the conception of knowledge as a mirror of nature (Rorty, 1979). But it follows the consequences a little further than the preceding critical approaches, showing subject and object as constantly 'shaping' one another within an ongoing symbolic vortex that is continuously redefined and re-signified. In Pearce's words, "their actions become part of this structuring process (...) that is never fixed, since it never crystallises" (1995, p. 266). It is, so, a game of permanent elaboration. And beyond the questioning of the dichotomy, social constructionism pronounces itself unambiguously as an anti-essentialist and anti-realist position, which can be understood as follows:

People and the social world are the result, the product, of specific social processes. This implies that neither people nor the world "possess" a determinate nature. (...) There are no natural objects: objects are what they are because we make them (...) The notion of object is a social convention and therefore dependent on our definition. Thus, there are no "natural" objects that exist 'in reality', independently, rather they are objectifications resulting from social practices that have instituted them as such (...) The same idea applies to psychological objects in the sense that they do not stem from a supposed 'human nature', but are also the result of practices of objectification. (...)

The constructionist view implies the denial of the relation between knowledge and any direct perception of reality, in the sense that "Reality" is only a set of versions collectively constructed 
by societies and cultures as a community throughout history. Reality" does not exist independently of the knowledge we produce or independently of any description we make of it (...). Consequently, it is in that sense that we say that we construct reality and that what we say about it is a matter of convention. There is no separation between reality and our knowledge of it. The object does not generate its representation but is rather constructed by our practices (...). (Íñiguez, 2003, p. 4).

With these reflections, constructionism takes the interpretative product out of the marginal space or, in other words, puts the focus on the relational production between subject and object. Consequently, the supremacy of objectivity over subjectivity is disarticulated, revealing instead a reciprocal construction through multiple layers of interpretation. These are simply the result of conventions agreed upon by speech communities that constitute themselves (in a cascade of effects) operating as if they were 'facts' to be 'discovered'. Method is a human and historically situated creation uncapable of neutrality since it is the result of conventions that circumstantially establish 'truth'. Above all, it is the human researcher, and the community where he/she belongs, who decide the criteria of validity in any regime of truth (Woolgar, 1991). There are no natural objects, there are only objectivations that are the result of conventional and normative agreements, that is, the result of social, continuous human procedures: "it means that reality does not exist independently of the practices through which we objectify it and, with it, construct it" (Ibáñez, 2001, p. 252), moreover, "if truth would depend on us, it would immediately cease to be the truth, and would lose all capacity to perform the regulatory functions assigned to it, which are none other than producing consensus and acceptance without the need to resort to force." (p. 254) [Italics in the original].

\section{Linguistic practices and discursivity}

Doing together involves subjects and objects as inseparable and shaped not by things, but by language. Not in a literal sense: it is not that the existence of objects is naively denied (a too-frequent criticism of this view). Instead, social constructionism simply shows the conventional character of 'objects': a door, for instance, is an object which, when not opened, offers a clear material resistance; but a door does not constitute the rectangle that separates two or more spaces, unless it has been agreed within a speech community that this should be called 'door' (and its shape, a 'rectangle'). So we use the convention, not the object itself, to interrelate between us. It is in this sense that we speak of a world not of objects, but of language.

Language does not have a purely nominative function. Instead, language is constructive and performative. Austin (1982) and Bakhtin (1982) are right when they say: the latter, that communication takes place in the utterance, not in the sentence, understanding by utterance that which manages to make meaning (in the example of the "door", the question would be: is the meaning "door" in the very word "door", in the consecutive series of phonemes "d", "o", and so on, or in the shared convention according to which a rectangle that opens and closes, delimits spaces, etc., is what we have agreed to understand as "door"?); and the former 
(Austin), when he asserts that we do things with words, not in the manner of instantaneous or automatic procedures, but by invoking action as a consequence of our discourse, that is, what we say or not say creates consequences and these displace positions, move tensions, create subjectivations..., in short, produce things.

Íniguez (2003), with regard to the performative act revealed by Austin, stresses that "it should be considered in terms of its efficacy (...) and the effects it produces. The performative act is not addressed, as we may suppose, to a subject existing before the act; on the contrary: strictly speaking, the act produces it". (p. 18). This is the aim of the constructionist agenda: to expose the deformations brought about by modern representationism because it ignored the agential role of language by considering it a simple medium or instrument to name reality according to a relation of truth by correspondence:

Our initial concern, then, is with the relationship between descriptive language and the world it purports to represent. The problem is not without consequences, since, as philosophers of science, we have long been aware that a theory is measured by the value it has in the market of scientific prediction to the extent that the theoretical language corresponds to events in the real world. If scientific language bears no determinate relation to events external to the language itself, its contribution to prediction becomes problematic, and scientific theory cannot be perfected by observation. The hope that knowledge can be superior through systematic observation turns out to be vain. More generally, the fundamental objectivity of scientific accounts can be questioned. If an explanatory account do not correspond to the world, then what does it warrant? This question is critical, given that the claim to objectivity has provided the primary basis for the broad authority that the sciences have asserted over the past century. (Gergen, 1996, p. 30)

Neither the everyday world of beings of language, i.e., of symbolisation, nor the scientific world, despite its rhetoric of objectivity, are able to escape historical determination. "Scientific knowledge uses concepts and categories that are strictly conventional, that is to say, they represent nothing, except for the fact that we have decided that they represent something. Nothing can represent anything if not by means of a purely conventional decision" (Ilbáñez, 2001, p. 249). [Italics in the original]. And the representation is not a safe way to reality, because their relationship is not a reflection, rather it is constructive and social.

Developing the premise of 'we refuse to posit an ontology' (Gergen, 1996), subverts to some degree the very understanding of reality (as a cultural discourse). Thus, social constructionism is a 'form of intelligibility' that refuses theoretical status. It is simply a perspective, an approach, even a programme, but to the extent that it would consolidate itself as such, it would jeopardise its own capacity for reflection.

Likewise, this "understanding in ascent" (Gergen, 1996, p. 45) has brought up new values of relativism from the dead end where it lasted for time immemorial, and especially during the early nineties of the last century, after having been looked upon with disdain and superficiality, accused of irresponsibility. A conception that has been, little by little, disproved thanks to the critical contributions coming from social 
constructionism, such as: situated knowledge, embodiment, performativity, the re-elaboration of social studies about science and technology (IIñiguez and Pallí, 2002); the discovery of new subjectivities and processes of subjectivisation; the dilution of dichotomies such as natural/social, person/object or individual/collective; reflexivity, mostly derived from the sociology of scientific knowledge; or even the Actor Network Theory (ANT); or the feminist epistemology, etc. (Íñiguez, 2003).

One of the most fruitful exercises of relativisation lies precisely in de-essentialisation, which is easy to include in the agenda of social constructionism, but quite another thing to carry out. A task that implies no less than questioning the hard Aristotelian principles of identity and non-contradiction. Certainly, it would be easier and simpler to avoid this task, which is no easy matter, but to do so would be to fall prey of what $\mathrm{Oz}$ (2001) calls "moral superiority". It should be noted that this task is not only a merit of critical social constructionism; Bergson (1947) already felt the fragility of solidly configured essences, and Lévinas (1997) warned of the prison-like character of all ontology. But social constructionism stresses the fact that any approach of this kind will succeed in revealing existing problems insofar as it is not part of a system, while remaining loyal to its capacity of striping bare conceptions, along with their effects.

Social constructionism is a possibility for understanding the world without ignoring that it implies a point of view; therefore, it does not abuse its power. Something similar to the result of Foucault's dispositif, as Agamben (1998) puts it, a sort of universals that are known not to be universals, but which function as an artefact of sustainability.

This is to say that constructionism offers no foundation, no ineluctable rationality, no means of establishing the basic superiority of any conclusive approach to knowledge. Rather, it is a form of intelligibility - a set of propositions, arguments, metaphors, narratives and the like - that welcome being inhabited. All constructionist analyses are a form of "selective realism", privileging certain "objects of analysis" (...) in order to achieve a rhetorical impact. At the same time, this type of analysis does not ask for an application of the true-false polarity, but rather invites the reader to participate: to collaborate in providing meaning and significance, to play with possibilities and practices consistent with this intelligibility, and to evaluate them against the alternatives. Constructionist approaches are like an invitation to dance, to play or to lead a way of life. Unlike the foundationalist, who restricts the range of appropriate ways of explaining, the constructionist does not abolish alternatives. For an empirical foundationalist, the phenomenological approach is suspect, rationalism agonising, and spiritualism anathema. For the empiricist, therefore, his competitors could be abandoned without serious loss to humanity. Likewise, phenomenologists and spiritualists could be pleased with the eradication of empiricism, and so we could continue along the spectrum of existing metatheories. However, since constructionism does not claim to be "true" - this is beyond question - it does not eliminate alternatives from the field. Rather, it prompts the question: what are the benefits and losses to our way of life that follow from each approach, in what sense do these discourses contribute to 
our well-being, and in what sense do they obfuscate our ends? Indeed, a discussion that would never end. (Gergen, 1996, p. 71)

What is the standpoint of social constructionism research? From all the above, we can say that it stands on its own possibilities, away from any 'definition' that would prescribe an invariable way of proceeding. Social constructionism is the possibility to stand without prohibiting, but rather encouraging, to move purported fixities. Perhaps this is the drive behind the confidence that we never think alone (Mc Namee, 1996; Shotter, 1996), rather we can only think with others. Following Shotter, Ian Parker points out that the "conceptions of the self (...) are so different across cultures, they constitute from social resources, themselves being indexical, constructed in relation to others" $(1999$, p. 96) [italics in the original], and this helps to "see knowledge not as a product of individual minds but of community relations". (Gergen, 2007, p. 218)

Concerning the criticisms, not always claiming to be realistic or objective, and even those coming from within social constructionism, Íñiguez (2003) argues:

... The question is not whether everything is a social construction or whether everything is discursively constructed, because when things are posed in this way, the constitutive force of performance is denied. (...) Thus, performativity is not only a linguistic action, an intentional speech act of the subject, but a form of power. (p. 19)

Following the drive of social constructionism does not imply a blindfold acceptation. Thinking always entails the possibility of dissent. We can understand the thinker as a polemicist arguing with others while in dialogue with another one, even if that one is himself (Billig, 1987). To put it in other terms, the reflexivity of knowledge broadens the limits, or moves them away. So, after this summary on critical constructionism, it should not be surprising to take new challenges from this point on.

Critical-discursive social constructionism is a possibility of inexhaustible practices, also conducive to other practices and tendencies. This includes recapitulating on the critical socio-constructionist task and, without abandoning it completely, finding other realms. This presentation, in particular, has been inspired by the possibility of Bergsonian durée (1947). A critical task also consisting in paying careful attention to one's own approach.

FUNDING: The authors did not receive any external funding.

CONFLICT OF INTEREST: The author declares no conflicts of interest. 


\section{REFERENCES}

- Agamben, Giorgio. (1998). Homo sacer: el poder soberano y la nuda vida [Homo Sacer: Sovereign Power and the Nuda Vida]. Valencia: Pre-Textos. ISBN: 978-84-8191-206-7, Available at: https://www.pre-textos.com/prensa/wp-content/uploads/2014/02/13-063-homo-sacer-_reed_pdf

- Austin, John. (1982). Cómo hacer cosas con palabras [How to Do Things with Words]. Barcelona: Paidós. ISBN: 84-7509-141-5. Available at: http://semiologia-cbcdistefano.com.ar/bibliografia/unidad-2/Complementaria/Austin-1982-Como-hacer-cosas-conpalabras.pdf

- Bakhtin, Mikhail. (1982). Estética de la creación verbal [Aesthetics of Verbal Creation. Mexico: Siglo XXI. ISBN: 968-23-1111-x. Available at: https://circulosemiotico.files.wordpress.com/2012/10/estetica-de-la-creacic3b3n-verbal.pdf

- Bergson, Henri. (1947). La evolución creadora. [Creative Evolution] Buenos Aires: Revista de Occidente Argentina. The text is available at: http://figuras.liccom.edu.uy/ media/figari:anexos:bergson henri - la evolucion creadora.pdf

- Billig, Michael. (1987). Arguing and Thinking: a Rhetorical Approach to Social Psychology. Cambridge: Cambridge University Press. ISBN: 978-0521327893. Available at: https://books.google.es/books/about/Arguing and Thinking.html?id=n0vFQgAACAAJ\&redir esc $=y$

- Comte, Auguste. (1974). Discurso sobre el espíritu positivo [Discourse on the Positive Spirit]. Bogotá: El Búho. The text is available at: https://cursosupla.files.wordpress.com/2016/04/comte-adiscurso-sobre-el-espc3adritu-positivo-1844.pdf

- Enaudeau, Corinne. (1999). La paradoja de la representación [The Paradox of Representation]. Buenos Aires: Paidós. ISBN: 950-12-6511-0. Available at: https://imaginariosyrepresentaciones.files.wordpress.com/2014/08/la-paradoja-de-larepresentacic3b3n-corinne-enaudeau-1.pdf

- Fernández-Ch, Pablo. (2010). Recetas de la cocina de la torre de marfil [Recipes from the Ivory Tower Kitchen]. Autonomous University of Mexico, Faculty of Psychology. Available at: http://www.ludus-vitalis.org/ojs/index.php/ludus/article/view/315

- Foucault, Michel. (1978a). "La crisis de la medicina o la crisis de la antimedicina". In Medicina e Historia. El pensamiento de Foucault ["The crisis of medicine or the crisis of anti-medicine". In Medicine and History]. Foucault's Thought]. Washington: Pan American Health Organization, p. 17-35. Available at: https://iris.paho.org/bitstream/handle/10665.2/39029/10077.pdf? sequence=1\&isAllowed=y

- Foucault, Michel. (1978b). "Incorporación del hospital a la tecnología moderna" ["Incorporation of the hospital into modern technology"]. Ibidem, p. 59-74. Available at: https://iris.paho.org/bitstream/handle/10665.2/39029/10077.pdf? sequence=1\&isAllowed=y

- Foucault, Michel. (1996). Las tecnologías del yo [Technologies of Self]. Barcelona: Paidós. Available at: https://philarchive.org/archive/DORLEE

- Foucault, Michel. (1997). Un diálogo sobre el poder y otras conversaciones [A Dialogue on Power and Other Conversations]. Madrid: Alianza. ISBN: 84-206-1816-0. Available at: https://museoetnografico.com/pdf/puntodefuga/181003focault2.pdf 
- Gadamer, Hans-George. (1977). Verdad y método [Truth and Method]. Salamanca: Sígueme. ISBN: 978-84-301-0463-5. Available at: http://www.sigueme.es/libros/verdad-y-metodo-i.html

- Gergen, Kenneth. (1996). Realidades y relaciones. Aproximaciones a la construcción social [Realities and Relations. Aproximations to Social Construction]. Barcelona: Paidós. Available at: https://www.academia.edu/3798319/Gergen realidades y relaciones

- Gergen, Kenneth. (2007). Construccionismo social, aportes para el debate y la práctica [Social Constructionism: Contributions to Debate and Social Practice]. Bogotá: Uniandes. ISBN: 978-958695-301-6. Available at: https://www.academia.edu/25119338/KENNETH_GERGEN_CONSTRUCCIONISMO_SOCI AL APORTES PARA EL DEBATE Y LA PR\%C $3 \% 81 \mathrm{CTICA}$ Uniandes Ceso Departament o de Psicolog $\%$ C $3 \%$ ADa

- Hobsbawm, Eric. (1989). La era de la revolución, 1789-1848. [The Era of Revolution, 1789-1848] Barcelona: Crítica. ISBN: 978-987-9317-14-3. Available at: http://resistir.info/livros/hobsbawm_la_era_de_las_revoluciones_1789_1848.pdf

- Ibáñez, Tomás. (1994), Psicología social construccionista [Constructionist Social Psychology]. Guadalajara: Universidad de Guadalajara (Mexico). ISBN: 9688959782. Available at: https://hacerypensar.files.wordpress.com/2015/08/psicologia-social-constructivistaibac3b1ez.pdf

- Ibáñez, Tomás. (1996). Fluctuaciones conceptuales en torno a la posmodernidad y la psicología [Conceptual Fluctuations around Postmodernity and Psychology]. Caracas: CEPFHE. ISBN: 9800010297.

- Ibáñez, Tomás. (2001). Psicología Social Construccionista [Constructionist Social Psychology]. Guadalajara: Universidad de Guadalajara (Mexico). ISBN: 9688959782. Available at: https://hacerypensar.files.wordpress.com/2015/08/psicologia-social-constructivistaibac3b1ez.pdf

- Ibáñez, Tomás. (2003). "La construcción social del socioconstruccionismo: retrospectiva y perspectivas", in Política y Sociedad ["The social construction of social-constructionism", in Politics and Society]. 2003, Vol. 40, No. 1, 155-160. Available at: https://revistas.ucm.es/index.php/POSO/article/view/24851

- Ibáñez, Tomás. (2005). Invitación al deseo de un mundo sin iglesias, alias, variaciones sobre el relativismo [Invitation to the desire for a world without churches, alias, variations on relativism]. Athenea Digital, 8, available at: https://atheneadigital.net/article/view/n8-ibanez/236-pdf-es

- Íñiguez, Lupicinio. (2003). "La psicología social en la encrucijada postconstruccionista. Historicidad, Subjetividad, Performatividad, Acción" [Social psychology at the post-constructionist crossroads. Historicity, Subjectivity, Performativity, Action]. Lecture presented at XII Encontro Nacional da ABRAPSO. Estratégias de invenção a Psicologia Social no contemporâneo, 15, 16 and 17 October 2003, Pontifícia Universidade Católica do Rio Grande do Sul, Porto Alegre, Brazil. Available at: http://abrapso.org.br/siteprincipal/index.php?option=com_content\&task=view\&id=135

- Íñiguez, Lupicinio and Pallí, Cristina. (2002). "La psicología social de la ciencia: revisión y discusión de una nueva área de investigación" [The social psychology of science: Review and discussion of a new area of research]. Anales de psicología, vol. 18, No. 1 (June), 13-43. Available at: https://www.redalyc.org/pdf/167/16718102.pdf 
- Lévinas, Emmanuel. (1997). Totalidad e infinito [Totality and Infinity]. Salamanca: Sígueme. ISBN: 978-84-301-1820-5. http://www.sigueme.es/libros/totalidad-e-infinito.html

- Mc Namee, Sheila. (1996). "La construcción relacional del significado. De la cabeza al discurso" [The relational construction of meaning. From head to discourse]. El talón de Aquiles, No. 4, Spring, (1996). Available

at: https://mypages.unh.edu/sites/default/files/sheilamcnamee/files/la_construccion_relacioinal_del significado.pdf

- Mead, George. (1973). Espíritu, persona y sociedad [Spirit, Person and Society]. Barcelona: Paidós. Available at: https://sicologias.files.wordpress.com/2015/01/01-mead-g-espiritu-persona-ysociedad.pdf

- Oz, Amos. (2001). Sobre la naturaleza del fanatismo [On the Nature of Fanaticism] in Contra el fanatismo [Against the fanaticism]. Siruela. ISBN: 9788478447084.

- Parker, Ian. (1999). "Humanismo y subjetividad en psicología" [Humanism and Subjectivity in Psychology]. Revista AVEPSO, Vol. XXII, No. 2, 1999.

- Pearce, Barnett. (1995). "Nuevos modelos y metáforas comunicacionales: el pasaje de la teoría a la praxis, del objetivismo al construccionismo social y de la representación a la reflexividad". In Schnitman, F. (coord.): Nuevos paradigmas, cultura y subjetividad. [New communicational models and metaphors: the passage from theory to praxis, from objectivism to social constructionism and from representation to reflexivity. In New Paradigms, Culture and Subjectivity] Buenos Aires: Paidós. Available at: https://xdoc.mx/documents/nuevos-modelos-y-metaforas-comunicacionalesel-pasaje-de-la-5f399a8de45a0

- Rorty, Richard. (1979). Philosophy and the mirror of nature. Princeton: University Press. ISBN: 9780691178158. Available

at: https://press.princeton.edu/books/paperback/9780691178158/philosophy-and-the-mirror-of$\underline{\text { nature }}$

- Shotter, John. (1996). "El lenguaje y la construcción del sí mismo". In: Pakman, Marcelo (Ed.): Construcciones de la experiencia humana. [Language and the Construction of the Self, in Constructions of Human Experience]. Barcelona: Gedisa. Available at: https://www.scribd.com/document/344026591/Marcelo-Pakman-Construcciones-de-laexperiencia-humana-vol-1-pdf

- Wallerstein, Immanuel. (1999). El legado de la sociología, la promesa de la ciencia social [The legacy of Sociology, the Promise of Social Science]. Caracas: Nueva Sociedad. ISBN: 980-317153-4. Available at: https://www.scribd.com/document/413417391/Immanuel-Wallerstein-ElLegado-de-La-Sociologia-La-Promesa-de-La-Ciencia-Social-1999-Editorial-Nueva-Sociedad

- Wallerstein, Immanuel. (2006). Abrir las ciencias sociales [Opening up the Social Sciences]. Mexico: Siglo XXI. ISBN: 968-23-2012-7. Available at: https://catedraepistemologia.files.wordpress.com/2012/04/wallerstein-immanuel-abrir-laciencias-sociales.pdf

- Woolgar, Steve. (1988). Science: The Very Idea. Chichester: Ellis Horwood, London: Tavistock. ISBN: 0-7458-0041-6. Available at: https://archive.org/details/scienceveryidea00wool/page/n3/mode/2up

- Woolgar, Steve. (1991). Ciencia: abriendo la caja negra [Science: Opening the Black Box]. Barcelona: Anthropos. Available 
at: https://www.yumpu.com/es/document/view/35917214/woolgar-steve-1991-ciencia-abriendo-lacaja-negra-barcelona-

\section{ABOUT THE AUTHOR}

Janicce Martinez Richard was born in Caracas, Venezuela. She has a Degree in Psychology (Magna cum laude) from the Universidad Central de Venezuela. Later, she studied in the Universidad Autónoma de Barcelona, where she obtained a Master's Degree, a Diploma of Advanced Studies, and a PhD in Social Psychology (Cum laude). She is currently Associate Professor at the Universidad Simón Bolivar, Caracas, where she conducts research in the area of epistemology from a psychosocial perspective. She has received awards and recognition for her research in social psychology. She is a member of the Centro de Investigaciones Educativas (CIES) of the Universidad Central de Venezuela, and has been a member of the editorial team of the Revista de Pedagogia, of the School of Education, Universidad Central de Venezuela (2012-2016). She has published books and peer-reviewed articles. 